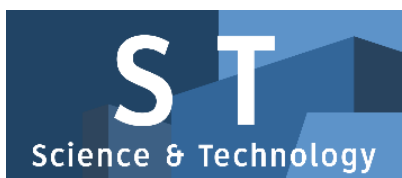

PAPER - OPEN ACCESS

\title{
Pembuatan Sabun Cair Dengan Alkali Kalium Abu Batang Pisang (Musa Paradisisaca)
}

$\begin{array}{ll}\text { Author } & : \text { Masniar Sirait } \\ \text { DOI } & : 10.32734 / \text { st.v1i2.298 } \\ \text { Electronic ISSN } & : 2654-7082 \\ \text { Print ISSN } & : 2654-7074\end{array}$

Volume 1 Issue 2-2018 TALENTA Conference Series: Science \& Technology (ST)

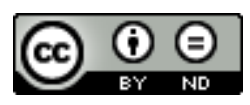

This work is licensed under a Creative Commons Attribution-NoDerivatives 4.0 International License.

Published under licence by TALENTA Publisher, Universitas Sumatera Utara
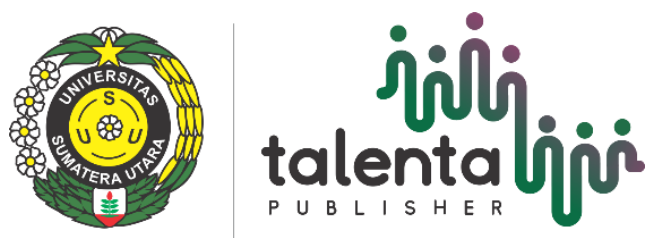


\title{
i \\ ST Conference Series 01 (2018), Page 194-203 \\ TALENTA Conference Series \\ Available online at https://talentaconfseries.usu.ac.id \\ Pembuatan Sabun Cair Dengan Alkali Kalium Abu Batang Pisang (Musa Paradisisaca)
}

\author{
Lilis Sukeksi ${ }^{\mathrm{a}}$, Masniar Sirait ${ }^{\mathrm{a}, *}$, Patima Valentina Haloho ${ }^{\mathrm{a}}$ \\ Fakultas Teknik, Universitas Sumatera Utara, Medan 20155 \\ sirait_masniar@yahoo.com
}

\begin{abstract}
Abstrak
Penelitian ini bertujuan mengetahui potensi kalium dari abu limbah batang pisang sebagai sumber alkali untuk dijadikan sabun cair alami.Penelitian ini diawali dengan mengeringkan batang pisang dan dilakukan pembakaran untuk memperoleh abu batang pisang. Pembakaran dilakukan dengan menggunakan muffle furnace pada suhu 550 oC selama 3 jam. Kemudian dilakukan ekstraksi pada abu dengan menggunakan aquadest dengan perbandingan $4: 25(\mathrm{w} / \mathrm{v})(\mathrm{gram} / \mathrm{ml})$ untuk memperoleh alkali. Alkali ini direaksikan dengan minyak kelapa "Barco" pada proses saponifikasi dengan variabel tetap volume minyak $30 \mathrm{ml}$, kecepatan pengadukan $250 \mathrm{rpm}$ dan waktu reaksi 3 jam. Sedangkan untuk variabel bebasnya suhu reaksi $60 \mathrm{oC}, 70 \mathrm{oC}, 80 \mathrm{oC}, 90 \mathrm{oC}$, volume alkali $40 \mathrm{ml}, 50 \mathrm{ml}, 60 \mathrm{ml}, 70 \mathrm{ml}$.Respon yang diamati adalah Keasaman $(\mathrm{pH})$, densitas, bilangan penyabunan dan alkali bebas. Hasil yang terbaik diperoleh pada suhu $80 \mathrm{oC}$ dan volume alkali $70 \mathrm{ml}$ dengan $\mathrm{pH}$ 10,1, densitas 1,064 gr/ml,bilangan penyabunan 198,939 dan kadar alkali bebasnya $0,0840 \%$.
\end{abstract}

Kata Kunci: Batang Pisang; pembakaran; abu; saponifikasi; sabun

\section{Pendahuluan}

Sabun telah berkembang menjadi kebutuhan primer di masyarakat dunia saat ini,yang dibuat melalui proses saponifikasi lemak atau gliserida dengan larutan alkali. Lemak atau gliserida yang digunakan dapat berupa lemak hewani, minyak nabati, lilin, ataupun minyak ikan laut [1]. Sabun termasuk salah satu jenis surfaktan yang mempunyai struktur bipolar, bagian kepala bersifat hidrofilik dan bagian ekor bersifat hidrofobik. Karena sifat inilah sabun mampu mengangkat kotoran (biasanya lemak) dari badan atau pakaian [2] dan dimanfaatkan setiap hari oleh semua kalangan masyarakat, baik kelas atas, menengah, maupun bawah. Industri sabun mandi pun berlomba-lomba menciptakan produk yang inovatif dan bermanfaat, bervariasi baik dari segi bentuk, warna, maupun aroma [3].

Produk sabun mandi berbasis bahan alam masih jarang ditemukan di pasaran [1]. Kebanyakan masih menggunakan bahan kimia seperti $\mathrm{KOH}$ dan $\mathrm{NaOH}$ sebagai alkali dan zat tambahan lainnya seperti diethanolamine (DEA), sodium lauryl sulfate (SLS), serta triclosan [4], yang banyak disorot karena berbahaya bagi kulit. Seiring perkembangan ilmu pengetahuan dan teknologi dibidang kimia dan farmasi, perkembangan kosmetik mulai bergeser ke arah produk natural (natural product) karena adanya tren kembali ke alam (back to nature) sehingga produksi sabun natural yang pembuatannya tidak melibatkan bahan kimia sintesis mulai di lirik para peneliti. Penggunaan bahan alami seperti kalium dari tumbuhan sebagai alkali dapat menggantikan bahan kimia sintetik yang digunakan pada pembuatan sabun sehingga lebih aman bagi kulit. Alkali alami dapat dihasilkan dari berbagai tumbuhan seperti serabut kelapa, kulitpisang, kulit cacao, tandan kosong kelapa sawit, dan salah satunya adalah batang pisang. 
Pisang (Musaa spp.) merupakan salah satu buah yang sangat populer di masyarakat karena mudah ditemukan dan tersedia dalam berbagai jenis. Budidaya buah pisang saat ini tidak hanya di lakukan sederhana seperti dipekarangan/kebun rumah, tetapi juga telah dilakukan secara intensif, terutama jenis pisang yang akan di ekspor [5]. Di Indonesia, tanaman pisang merupakan hasil pertanian yang banyak dan melimpah. Biasanya setelah panen, batang pisang hanya dibuang sebagai limbah sehingga menjadi tumpukan sampah yang dapat mencemari lingkungan. Batang pisang merupakan limbah terbesar yang diperoleh dengan nilai ekonomis yang hampir tidak ada [6]. Hasil penelitian Mohpatra, dkk., 2010 [7] menyatakan bahwa batang pisang mengandung kalium sebesar 33,4\% berbasis abu, sehingga hasil ekstrak abu batang pisang yang mengandung kalium dapat dimanfaatkan sebagai alkali alami dalam pembuatan sabun.

Selain alkali seperti kalium dan natrium untuk menghasilkan sabun natural, Bahan baku utama yang lain adalah asam lemak. Asam lemak yang digunakan dalam penelitian ini berasal dari minyak kelapa. Tanaman kelapa (Cocos nucifera) mendapat julukan pohon kehidupan, karena mulai dari akar, batang, daun, bunga dan buah dapat di manfaatkan untuk memenuhi sebagian besar kebutuhan manusia. Salah satu produk kelapa adalah minyak kelapa yang dibuat dari daging buah kelapa yang diolah. Minyak mengandung asam lemak esensial seperti asam oleat, linoleat, dan linolenat [8]. Sabun dari minyak kelapa memiliki kelebihan seperti; memiliki aroma manis berbau unik, anti-jamur dan memiliki busa yang banyak yang berfungsi sebagai emollient alami. Manfaat emollient untuk mengurangi kehilangan cairan pada permukaan kulit (yang menyebabkan kulit kering), melembutkan dan menghaluskan [9].

\subsection{Teori}

Sabun adalah garam dari senyawa asam lemak yang terbentuk dari reaksi saponifikasi, dimana ester dibagi menjadi alkohol dan garamnya [10]. Sebuah molekul sabun memiliki rantai hidrokarbon panjang dengan kelompok asam karboksilat pada salah satu ujungnya, yang memiliki ikatan ion dengan ion logam, biasanya natrium atau kalium.

Sabun memiliki struktur kimiawi dengan panjang rantai karbon C12 hingga C16 dan bersifat ampifilik, yaitu pada bagian kepalanya memiliki gugus hidrofilik (polar), sedangkan pada bagian ekornya memiliki gugus hidrofobik (non polar). Oleh sebab itu, dalam fungsinya, gugus hidrofobik akan mengikat molekul lemak dan kotoran, yang kemudian akan ditarik oleh gugus hidrofilik yang dapat larut di dalam air [1].

Kandungan zat-zat yang terdapat pada sabun juga bervariasi sesuai dengan sifat dan jenis sabun.Larutan alkali yang biasa digunakan pada sabun keras (sabun padat) adalah Natrium Hidroksida $(\mathrm{NaOH})$ dan alkali yang biasa digunakan pada sabun lunak (sabun cair) adalah Kalium Hidroksida (KOH) [11][12].

Proses pembuatan sabun dikenal dengan istilah saponifikasi. Saponifikasi adalah reaksi hidrolisis asam lemak oleh adanya basa lemah/kuat. Berikut merupakan reaksi saponifikasi:

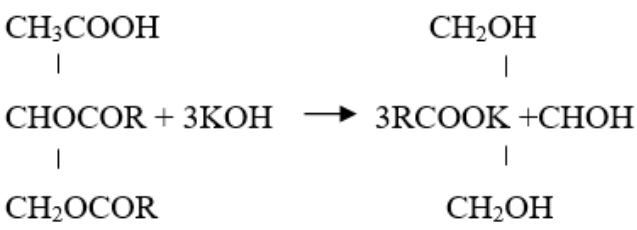

Fig. 1 Lemak Alkali Sabun Gliserol

Syarat mutu sabun mandi cair menurut standar nasional Indonesia [16] dapat di lihat pada Tabel 1. 
Table. 1 Syarat Sabun Mandi Cair

\begin{tabular}{llll}
\hline No & Kriteria & Satuan & Standar \\
\hline 1 & $\mathrm{pH}$ & $\%-11$ & Maks 0.1 \\
2 & Alkali Bebas & $\%$ & $1.01-1.1$ \\
3 & Bobot Jenis & $\mathrm{gr} / \mathrm{cm}^{3}$ & $196-206 *[1]$ \\
4 & Bilangan Penyabunan & & 196 \\
\hline
\end{tabular}

\section{Metodologi Penelitian}

\subsection{Bahan Baku dan Peralatan}

Bahan yang digunakan dalam penelitian ini adalah batang pisang, minyak kelapa "Barco", aquadest, asam klorida, indikator phenolphthalein, kalium hidroksida dan etanol

Alat yang digunakan meliputi Muffle furnace,cawan petri, neraca elektrik, beaker glass, Erlenmeyer, termometer, oven, aluminium foil, magnetik Stirrer, gelas ukur, Stopwatch, spatula, piknometer, pipet tetes, buret, statif dan klem, $\mathrm{pH}$ meter, kertas saring.

\subsection{Prosedur Saponifikasi}

Proses saponifikasi diawali dengan mereaksikan minyak kelapa dengan filtrate abu batang pisang diatas sebuah hot plate sesuai dengan perbandingan variable suhu dan volume filtrat. Lalu melakukan pengadukan selama 3 jam. Hasil saponifikasi yang diperoleh dipisahkan dengan menggunakan corong pemisah untuk memisahkan sabun.

\subsection{Analisa Densitas Sabun}

Proses saponifikasi diawali dengan mereaksikan minyak kelapa dengan filtrate abu batang pisang diatas sebuah hot plate sesuai dengan perbandingan variable suhu dan volume filtrat. Lalu melakukan pengadukan selama 3 jam. Hasil saponifikasi yang diperoleh dipisahkan dengan menggunakan corong pemisah untuk memisahkan sabun.

\subsection{Analisa Densitas Sabun}

Untuk menentukan densitas sabun ditimbang piknometer kosong dan kering dicatat massanya. Piknometer $10 \mathrm{ml}$ diisi dengan air hingga penuh. Ditimbang piknometer yang berisi dengan air dan dicatat masssanya. Selisih antara piknometer yang berisi air dan piknometer kosong adalah massa air. Dihitung volume air dengan rumus.

$$
V=\frac{m}{p}
$$

Kemudian piknometer diisi dengan sampel sebanyak volume sampel. Ditimbang volume piknometer berisi sampel dan dicatat masanya. Selisih antara piknometer berisi sampel dan piknometer kosong adalah massa sampel. Kemudian dihitung densitas sampel dengan persamaan:

$$
\rho_{\text {sampel }}=\frac{m_{\text {sampel }}}{m_{\text {air }}} \times \rho_{\text {air }}
$$




\subsection{Analisa Keasaman $(p H)$}

Disiapkan 5 gram sampel yang akan dianalisa pH nya. Dilarutkan sampel dalam $10 \mathrm{ml}$ aquadest. Dicuci $\mathrm{pH}$ meter dengan aquadest dan dilakukan kalibrasi dengan larutan buffer. Dimasukkan $\mathrm{pH}$ meter ke dalam larutan sampel. Dicatat $\mathrm{pH}$ yang tampil.

\subsection{Analisa Bilangan Penyabunan}

Ditimbang 2 gram sampel sabun dan dicampurkan dengan $25 \mathrm{ml}$ potassium Hydroxide Etanol 0,5 mol/L. Campuran direfluks selama 30 menit. Didinginkan dan ditambahkan Phenolptalein. Dititrasi dengan $\mathrm{HCl} \mathrm{0,1} \mathrm{mol/L}$ dan dicatat volume $\mathrm{HCl}$ yang terpakai. Dilakukan titrasi blangko. Dihitung bilangan penyabunan dengan rumus :

$$
P=\frac{C L x(V b-V a) x T F}{W}
$$

$$
\begin{array}{ll}
\mathrm{P} & \text { = bilangan penyabunan } \\
\mathrm{Vb} & =\text { volume titrasi blanko }(\mathrm{ml}) \\
\mathrm{Va} & =\text { volume titrasi }(\mathrm{ml}) \\
\mathrm{Cl} & =\text { konsentrasi konversi koefisien }(28,05) \\
& \quad \text { (potassium hydroxide ex. } 56,11 \times 0,5) \\
\mathrm{TF} & =\text { faktor reagen }(1,006) \\
\mathrm{W} & \quad \text { = berat }(\text { gram })
\end{array}
$$

\subsection{Analisa Kadar Alkali Bebas}

Siapkan alkohol netral dengan mendidihkan $100 \mathrm{ml}$ alkohol, tambahkan 0,5 ml indikator Phenolphetalein. Ditimbang 5 gram sampel dan masukkan kedalam alkohol netral, pasang refluks kondensor dan didihkan selama 30 menit. Larutan bersifat alkali (penunjuk Phenolphtalein berwarna merah). Lakukan uji alkali bebas dengan mentiternya menggunakan HCL 0,1 N dalam alkohol dari buret, sampai warna merah tepat hilang. Dihitung kadar alkali bebas dengan rumus:

$$
\text { alkali bebas }=\frac{V \times 0,056 \times N}{W} \times 100 \%
$$

\footnotetext{
$\mathrm{V}=$ volume $\mathrm{HCl}$ yang digunakan $(\mathrm{ml})$

$\mathrm{N} \quad=$ normalitas $\mathrm{HCl}$ yang $\operatorname{digunakan}(\mathrm{N})$

$\mathrm{W} \quad=$ berat sampel (gram)
} 


\section{Hasil Dan Pembahasan}

\subsection{Hasil Penelitian}

Karakteristik SEM EDX alkali dari kulit buah kapuk dilakukan untuk mengidentifikasi kandungan kalium yang ada pada abu batang pisang. Dari hasil analisa SEM-EDX yang dilakukan diperoleh persentase yang ada pada abu sebesar $33,4 \%$ kalium dan $11,9 \%$ sodium pada suhu pembakaran 550oC selama 3 jam.

Penggunaan perbandingan pelarut dan abu yang akan di ekstraksi pada penelitian ini pada perbandingan abu dan pelarut aquadest dengan sebesar4 : $25(\mathrm{w} / \mathrm{v})(\mathrm{gram} / \mathrm{ml})$ dan di diamkan selama 3 hari. Setelah dianalisa secara titrimetri diperoleh konsentrasi kalium sebesar $0,816 \mathrm{~N}$.

\subsection{Pengaruh Volume Larutan Alkali Terhadap Keasaman (Ph) Sabun Cair Pada Suhu Reaksi Yang Berbeda}

Nilai pH atau kadar keasaman merupakan salah satu parameter penting dalam penentuan mutu sabun yang digunakan untuk menyatakan tingkat keasaman (konsentrasi ion hidrogen dalam pelarut air) suatu larutan [15]. Nilai pH biasanya dianalisa dengan menggunakan alat yaitu pH meter. Menurut Wijana, dkk., (2009) [16] nilai pH menentukan kelayakan sabun untuk digunakan sebagai sabun mandi, jika terlalu tinggi atau terlalu rendah dapat menyebabkan kerusakan pada lapisan luar atau dalam bagian kulit [17]. Penambahan volume larutan alkali pada suhu yang berbeda mempengaruhi nilai $\mathrm{pH}$ dari sabun cair yang dihasilkan. Berikut grafik yang menunjukkan pengaruh volume larutan alkali terhadap keasaman (ph) pada suhu reaksi yang berbedadari sabun cair yang dihasilkan:

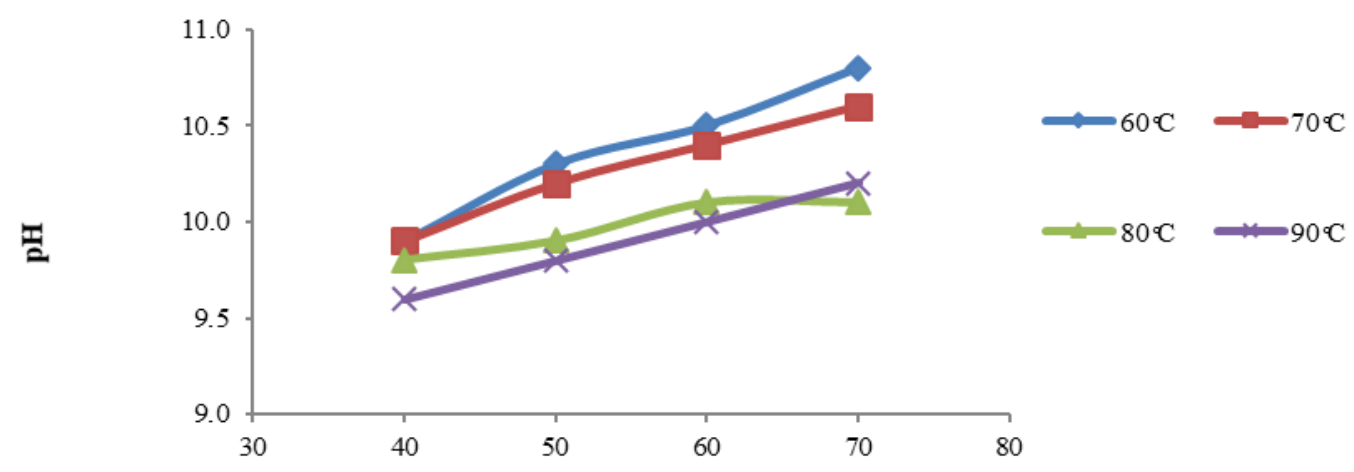

Volume Larutan Alkali (mI)

Fig. 2 Gambar 1 Grafik Pengaruh Volume Larutan Alkali Terhadap Keasaman (Ph) Sabun Cair Pada Suhu Reaksi Yang Berbeda

Dari Gambar 1 menunjukkan hubungan antara volume larutan alkali terhadap keasaman (ph) pada suhu reaksi yang berbedadari sabun cair yang dihasilkandapat dilihat bahwa nilai kadar keasaman $(\mathrm{pH})$ tertinggi adalah pada suhu $60 \mathrm{oC}$, volume larutan alkali70 $\mathrm{ml}$ yaitu 10,8. Sedangkan nilai $\mathrm{pH}$ terendah adalah pada variasi suhu $90 \mathrm{oC}$, volume larutan alkali $40 \mathrm{ml}$ yaitu 9,6.

Dari Gambar 1 dapat dilihat bahwasemakin besar volume larutan alkali yang digunakan akan meningkatkan $\mathrm{pH}$ sabun cair. Menurut penelitian yang dilakukan Budi, dkk., (2008) [18] kenaikan volume larutan alkali mengakibatkan konsentrasi alkali semakin tinggi. Dimana konsentrasi larutan berbanding lurus dengan $\mathrm{pH}$, semakin besar konsentrasi maka pH akan semakin besar pula. Sementara semakin bertambah besarsuhu reaksi penyabunan akan menyebabkan nilai $\mathrm{pH}$ sabun cenderung menurun sampai titik terendah. Hal ini terjadi karenakenaikan suhu akan mempercepat laju reaksi [18] sehingga menyebabkan waktu interaksi antara minyak dan alkali semakin besar, 
maka reaksi akan mendekati kesetimbangan sehingga residu alkali semakin rendah yang mengakibatkan sabun tidak terlalu basa.

Nilai pH larutan sabun bergantung pada jenis lemak, sebagai contoh sabun yang dibuat dari minyak kelapa mempunyai $\mathrm{pH}$ antara 9 dan 10, sedangkan sabun dari lemak hewani memberikan $\mathrm{pH}$ sekitar 10,8 [54]. Sabun yang diperoleh pada penelitian ini memiliki pH antara 9,8-10,8 dan menurut SNI pH sabun cair berkisar antara $8-11$ [16]. Jadi sabun yang diperoleh pada penelitian telah sesuai dan layak untuk digunakan.

\subsection{Pengaruh Volume Larutan Alkali Terhadap Densitas Sabun Cair Pada Suhu Reaksi Yang Berbeda}

. Densitas atau massa jenis adalah jumlah zat yang terkandung dalam suatu unit volume atau perbandingan berat dari suatu volume, contoh berat air pada volume dan suhu yang sama. Densitas dapat dianalisa dengan menggunakan piknometer. Penambahan volume larutan alkali pada suhu yang berbeda mempengaruhi nilai densitas dari sabun cair yang dihasilkan. Berikut grafik yang menunjukkan pengaruh volume larutan alkali terhadap densitas pada suhu reaksi yang berbedadari sabun cair yang dihasilkan:

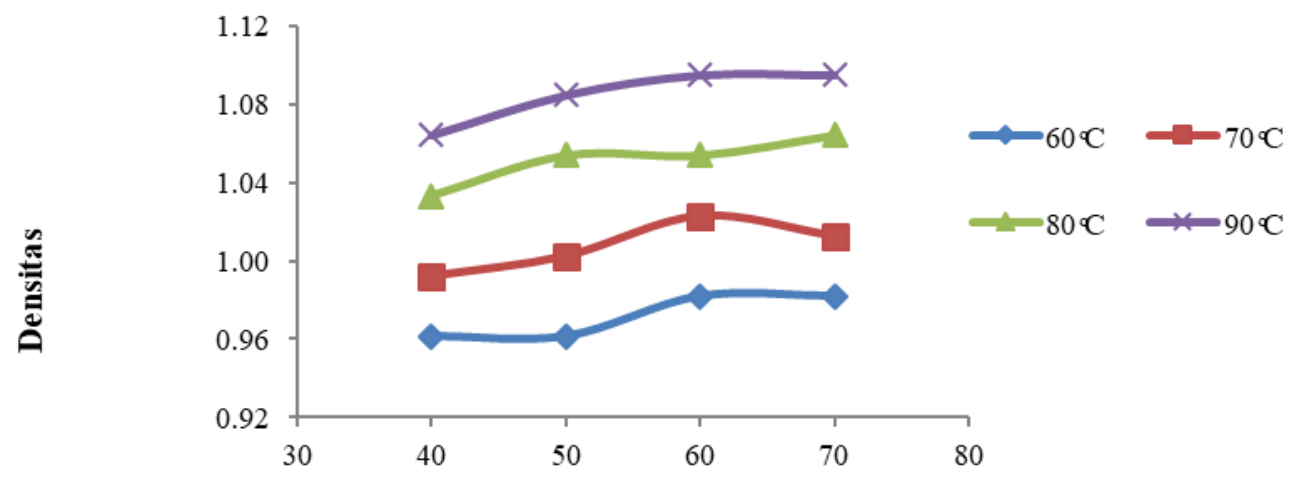

Volume Larutan Alkali (ml)

Fig. 3 Grafik Pengaruh Volume Larutan Alkali Terhadap Densitas Sabun Cair Pada Suhu Reaksi Yang Berbeda

Gambar 2 menunjukkan hubungan antara volume larutan alkali terhadap densitas pada suhu reaksi yang berbedadari sabun cair yang dihasilkan dapat dilihat bahwa densitas tertinggi adalah pada suhu 90 oC, volume larutan alkali70 $\mathrm{ml}$ yaitu $1,095 \mathrm{gr} / \mathrm{ml}$. Sedangkan densitas terendah adalah pada variasi suhu $60 \mathrm{oC}$, volume larutan alkali $40 \mathrm{ml}$ yaitu $0,962 \mathrm{gr} / \mathrm{ml}$.

Dari Gambar 2 diatas dapat dilihat bahwa suhu dan volume larutan alkali berpengaruh terhadap densitas sabun yang dihasilkan. Densitas sabun cenderung naik seiring dengan bertambahnya volume larutan alkali dalam reaksi penyabunan. Menurut penelitian yang dilakukan Budi, dkk., (2008) [18] semakin tinggi volume larutan alkali berarti konsentrasi alkali akan semakin tinggi. Berdasarkan stokiometri reaksi, penambahan alkali yang lebih ekses dari minyak menyebabkan minyak tersabunkan dengan sempurna sehingga yield yang dihasilkan tinggi dan mengakibatkan sabun yang dihasilkan lebih kental.Sementara pengaruh suhu reaksi terhadap densitas sabun akan semakin meningkat seiring dengan semakin besarnya suhu reaksi penyabunan. Menurut Wijana, dkk., (2009) [16] adanya partikel $\mathrm{H} 2 \mathrm{O}$ yang mulai menguap, sehingga kandungan air pada sabun akan berkurang sehingga sabun menjadi mengental. Penurunan viskositas akibat peningkatan rasio air/sabun dikarenakan viskositas dipengaruhi oleh kadar air dalam sabun tersebut [16].Viskositas merupakan densitas perwaktu, jika viskositas sabun meningkat dengan turunnya rasio air/sabun, maka densitas sabun akan meningkat dengan semakin sedikitnya kandungan air didalam sabun yang ditandai dengan mengental nya sabun yang dihasilkan. 
Sabun yang dihasilkan pada penelitian memiliki densitas antara 0,962 - 1,095 (gr/ml) menurut SNI densitas sabun berkisar 1,01 - 1,1 [13].Dari penelitian yang telah dilakukan ada beberapa densitas sabun yang sesuai dan tidak sesuai dengan SNI.

\subsection{Pengaruh Volume Larutan Alkali Terhadap Bilangan Penyabunan Sabun Cair Pada Suhu Reaksi Yang Berbeda}

Bilangan penyabunan adalah banyaknya alkali yang dibutuhkan untuk menyabunkan sejumlah minyak. Semakin tinggi bilangan penyabunan menunjukkan semakin tinggi pula kadar asam lemak bebas pada minyak sehingga alkali yang dibutuhkan untuk menyabunkan minyak tersebut juga akan semakin banyak [19]. Angka penyabunan dalam penelitian ini ditentukan dengan titrimetri. Penambahan volume larutan alkali pada suhu yang berbeda mempengaruhi bilangan penyabunan dari sabun cair yang dihasilkan. Berikut grafik yang menunjukkan pengaruh volume larutan alkali terhadap bilangan penyabunan pada suhu reaksi yang berbedadari sabun cair yang dihasilkan:

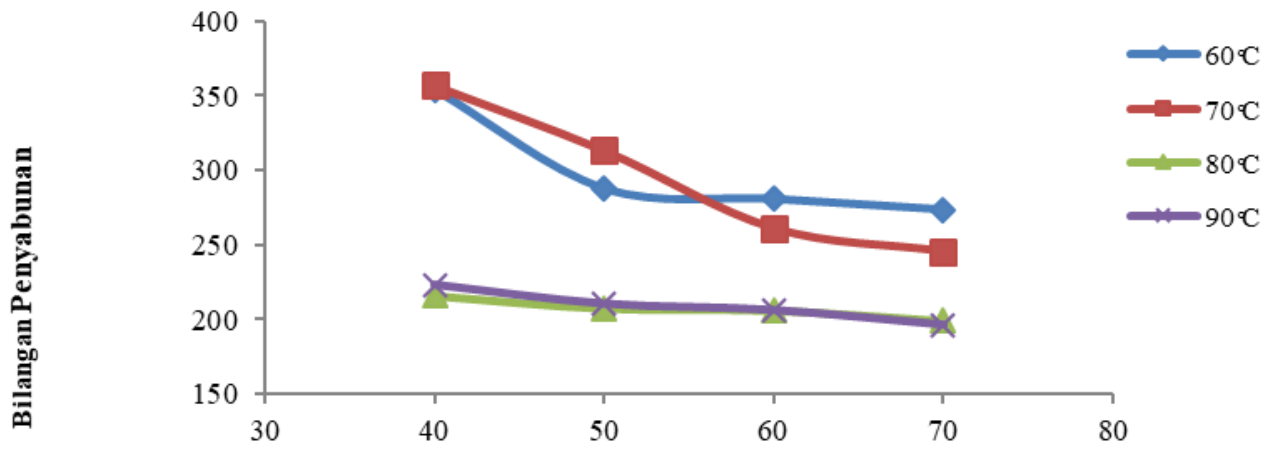

Volume Larutan Alkali (ml)

Fig. 4 Grafik Pengaruh Volume Larutan Alkali Terhadap Bilangan Penyabunan Sabun Cair Pada Suhu Reaksi Yang Berbeda

Grafik 4 menunjukkan hubungan antara volume larutan alkali terhadap bilangan penyabunan pada suhu reaksi yang berbedadari sabun cair yang dihasilkandapat dilihat bahwa nilai bilangan penyabunan tertinggi adalah pada suhu $70 \mathrm{oC}$, volume larutan alkali40 $\mathrm{ml}$ yaitu 356,961. Sedangkan nilai bilangan penyabunan terendah adalah pada variasi suhu 90 oC, volume larutan alkali $70 \mathrm{ml}$ yaitu 196,117.

Dari Gambar 4 diatas dapat dilihat bahwa adanya pengaruh suhu dan volume larutan alkali terhadap nilai bilangan penyabunan. Dengan semakin bertambahnya volume larutan alkali menyebabkan nilai bilangan penyabunan akan semakin menurun. Hal ini disebabkan oleh semakin bertambahnya volume larutan alkali menyebabkan konsentrasinya semakin besar [18]. Sehingga semakin banyak alkali yang bereaksi dengan asam lemak pada minyak mengakibatkan sisa asam lemak pada sabun yang dihasilkan setelah reaksi saponifikasi akan semakin sedikit, maka saat dilakukan penambahan $\mathrm{KOH}$ kembali pada analisa angka penyabunan menyebabkan $\mathrm{KOH}$ berlebih yang terdapat pada sampel sabun semakin besar. Hal ini terjadi karena asam lemak bebas dalam minyak telah tersabunkan pada saat penggunaan konsentrasi alkali dan suhu tinggi pada reaksi sebelumnya, sehingga $\mathrm{HCl}$ yang dibutuhkan untuk mengetahui $\mathrm{KOH}$ berlebih juga semakin kecil (Volume titrasi $\mathrm{HCl}$ semakin kecil maka bilangan penyabunan semakin besar). Sementara pengaruh suhu reaksi terhadap bilangan penyabunan akan semakin turun seiring dengan semakin besarnya suhu reaksi. Menurut kurnia (2010) [20] dan Walter (2000) [21] bahwa pada kisaran suhu tertentu, kenaikan suhu akan mempercepat reaksi penyabunan, yang artinya menaikkan hasil dalam waktu yang lebih cepat. Tetapi jika kenaikan suhu telah melebihi suhu optimum, akan menyebabkan pengurangan hasil karena harga kesetimbangan konstanta reaksi K akan turun yang berarti reaksi akan 
bergeser kearah pereaksi atau dengan kata lain produk akan berkurang. Reaksi yang jauh dari kesetimbangan akan menghasilkan sabun dengan nilai bilangan penyabunan yang besar.

Sabun hasil penelitian memiliki bilangan penyabunan antara 196,12 - 356,961 dan menurut SNI nilai bilangan penyabunan adalah antara 196 - 206 (Indonesia dan Nasional 1994). Dari hasil penelitian yang sesuai dengan SNI adalah pada suhu $80 \mathrm{oC}$ rasio volume minyak dan larutan alkali 60 dan $70 \mathrm{ml}$ yaitu berturut-turut sebesar sebesar 198,94 dan 205,99, serta suhu 90 oC rasio volume minyak dan larutan alkali 60 dan $70 \mathrm{ml}$ sebesar 205,99 dan 196,12 .

\subsection{Pengaruh Volume Larutan Alkali Terhadap Kadar Alkali Bebas Sabun Cair Pada Suhu Reaksi Yang Berbeda}

Kadar alkali bebas merupakan salah satu parameter yang sangat penting dalam penentuan mutu suatu sabun, karena nilai kadar alkali bebas menentukan kelayakan sabun cair untuk digunakan sebagai sabun mandi. Jika kadar alkali bebas pada sabun melebihi standar yang telah ditetapkan dapat menyebabkan iritasi pada kulit, seperti kulit luka dan mengelupas [24]. Kadar Alkali bebsa dalam penelitian ini ditentukan dengan titrimetri. Penambahan volume larutan alkali pada suhu yang berbeda mempengaruhi kadar alkali bebas dari sabun cair yang dihasilkan. Berikut grafik yang menunjukkan pengaruh volume larutan alkali terhadap kadar alklai bebas pada suhu reaksi yang berbedadari sabun cair yang dihasilkan:

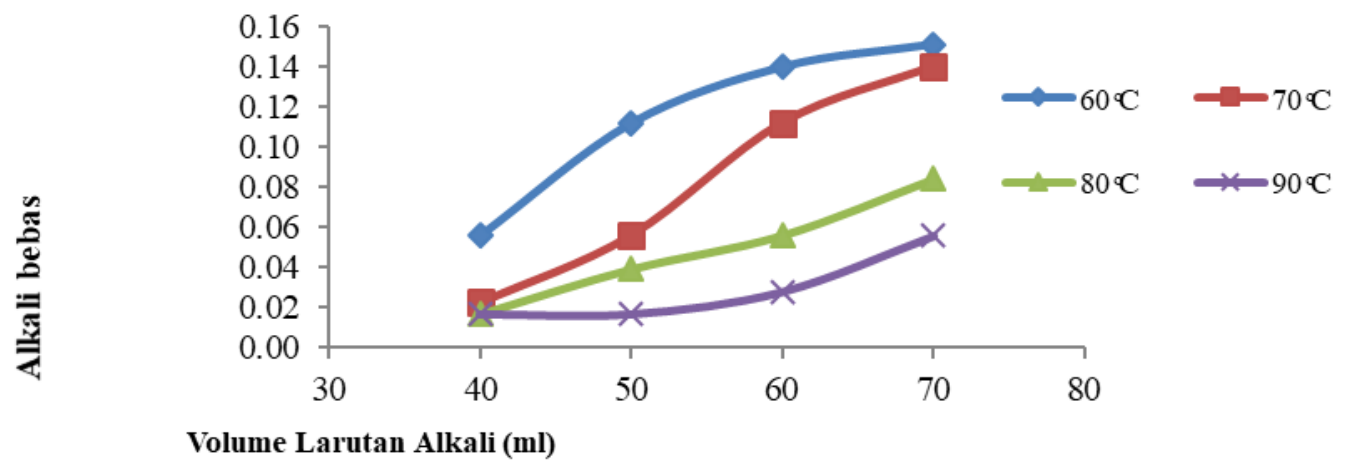

Fig. 5 Grafik Pengaruh Volume Larutan Alkali Terhadap Kadar Alkali Bebas Sabun Cair Pada Suhu Reaksi Yang Berbeda

Dari Gambar 5 menunjukkan hubungan antara volume larutan alkali terhadap kadar alklai bebas pada suhu reaksi yang berbedadari sabun cair yang dihasilkandapat dilihat bahwa nilai kadar alkali bebas tertinggi adalah pada suhu $60 \mathrm{oC}$, volume larutan alkali70 $\mathrm{ml}$ yaitu $0,1512 \%$. Sedangkan nilai bilangan penyabunan terendah adalah pada variasi suhu $90 \mathrm{oC}$, volume larutan alkali $40 \mathrm{ml}$ yaitu $0,0168 \%$.

Dari Gambar 5 tersebut dapat dilihat adanya pengaruh suhu dan volume larutan alkali terhadap kadar alkali bebas. Dengan semakin besarnya suhu reaksi penyabunan menyebabkan kadar alkali bebas pada sabun menurun sampai pada titik terendah. Berdasarkan penelitian yang telah dilakukan oleh Wijana, dkk., (2009) [16], kadar alkali bebas memiliki kecenderungan akan semakin menurun akibat semakin besar nya suhu reaksi dan waktu pengadukan pada proses pembuatan sabun. Pada kisaran suhu tertentu, kenaikan suhu akan mempercepat reaksi penyabunan, yang artinya menaikkan hasil dalam waktu yang lebih cepat. Tetapi jika kenaikan suhu telah melebihi suhu optimum, akan menyebabkan terjadinya pengurangan hasil karena harga kesetimbangan konstanta reaksi $\mathrm{K}$ akan turun yang berarti reaksi akan bergeser kearah pereaksi atau dengan kata lain produk akan berkurang [18]. Turunnya harga konstanta kesetimbangan reaksi oleh naiknya suhu merupaan akibat dari reaksi penyabunan yang bersifat eksotermis [60]. Reaksi yang jauh dari kesetimbangan akan menghasilkan sabun dengan kadar alkali yang besar. Adanya peningkatan kadar alkali bebas ini juga disebabkan banyaknya air yang menguap pada larutan, karena air dapat menurunkan konsentrasi alkali bebas pada sabun (Wijana, 2009) [54]. Sementara dengan meningkatnya volume larutan alkali akan mengakibatkan kadar alkali bebas meningkat. Menurut penelitian yang dilakukan Muhlisin (2014) [61] bahwa 
hal ini dikarenakan tidak ada lagi minyak yang dapat disabunkan oleh alkali, sehingga terdapat kelebihan alkali yang tidak bereaksi dengan minyak.

Sabun hasil penelitian memiliki kadar alkali bebas antara 0,1512 - 0,0168 \% dan standar kadar alkali bebas menurut SNI adalah 0,14\% [17].Dari hasil penelitian kadar alkali bebas yang dihasilkan telah memenuhi SNI. Kecuali kadar alkali pada suhu 60 oC rasio volume minyak dan larutan alkali $70 \mathrm{ml}$ sebesar $0,1512 \%$

\section{Kesimpulan}

Kesimpulan yang diperoleh dari penelitian ini adalah:

- 1. Nilai pH yang diperoleh dari hasil penelitian sudah sesuai dengan SNI yaitu sekitar 9,8-10,8.

- 2. Densitas sabun yang diperoleh dari hasil penelitian yang sesuai dengan SNI yaitu pada suhu 70,80 , dan $90{ }^{\circ} \mathrm{C}$ dengan volume larutan alklai 40, 50, 60, dan $70 \mathrm{ml}$.

- 3. Nilai bilangan penyabunan yang terbaik pada penelitian ini diperoleh pada suhu 80 dan 90 oC dengan volume larutan alkali 60 dan $70 \mathrm{ml}$

- 4. Nilai kadar alkali bebas pada penelitian ini yang tidak sesuai SNI yaitu pada suhu 60 oC dengan larutan alkali $70 \mathrm{ml}$.

- 5. Dari hasil sabun cair yang dihasilkan,abu batang pisang (Musa paradisiaca) dapat digunakan sebagai bahan baku alkali pada pembuatan sabun natural.

\section{Saran}

Adapun saran yang dapat diambil daripenelitianyang telah dilakukan adalah:

- Untuk penelitian selanjutnya sebaiknya melakukan variasi pada waktu pengadukan agar diperoleh hasil yang lebih baik.

- Untuk penelitian selanjutnya sebaiknya melakukan perendaman abu secara batch sampai pelarutnya jenuh dalam menyerap kalium dari abu batang pisang yaitu perendaman dilakukan dengan cara, abu direndam selama tiga hari, kemudian di filtrasi dan ditambah kembali abu kedalam filtrat sesuai dengan filtrat yang dihasilkan sampai filtrat jenuh dengan alkali yang terekstraksi.

- Untuk penelitian selanjutnya sebaiknya melakukan pembersihan dan pengeringan terhadap alat sebelum digunakan. Karena pada saat titrasi akan mempengaruhi hasil titrasi.

\section{Daftar Pustaka}

[1] [1] Naomi, Phatalina, Anna M Lumban Gaol dan M Yusuf Toha. 2013. Pembuatan Sabun Lunak dari Minyak Goreng Bekas Ditinjau dari Kinetika Reaksi Kimia. Jurnal Teknik Kimia, No. 2, Vol. 19.

[2] Sari, Vonny Indah. 2012. Pemanfaatan Stearin Dalam Proses Pembuatan Sabun Mandi Padat. Jurnal Teknik Pengolahan Sawit, Vol 11, No 1.

[3] Nurhadi, Siely Cicilia. 2012. Pembuatan Sabun Mandi Gel Alami dengan Bahan Aktif Mikroalga Chlorella pyrenoidosa Beyerinck dan Minyak Atsiri Lavandula latifolia Chaix. Skripsi. Malang : Universitas Ma Chung.

[4] Nurama, yeni, Suhartiningsih. 2014. Pengaruh Penambahan Sari Belimbing Wuluh Terhadap Sifat Fisik Sediaan Sabun Wajah Berbentuk Cair. E-journal. Volume 03 Nomor 01 hal 251-259.

[5] Rohmah, Yuliawati. 2016. Outlook Komoditas Pisang. Pusat Data dan Kementrian Informasi Pertanian Kementrian Pertanian. ISSN : 19071507.

[6] Erwin, Oktavyarni Patibon, Subur P. Pasaribu. 2014. Pemanfaatan Abu Batang Pisang (Musa paradisiaca) Dengan Variasi Berat Abu Sebagai Katalis Dalam Pembuatan Biodiesel Dari Minyak Jelantah. Indonesia Chimica Acta, Vol.7, No.2. ISSN 2085-014X.

[7] Mohapatra, Debabandya, Sabyasachi Mishra, and Namrata Sutar. 2010. Banana and Its by-Product Utilisation : An Overview. Journal of Scientific \& Industrial Research Vol.69, Hal 323-329.

[8] Patty, Paulus Valentino. 2015. Pengaruh Lama Fermentasi Terhadap Ranciditas Minyak Kelapa Yang Diproduksi Secara Tradisional. Biopedix, Vol. 1, No.2, Hal. 137-142.

[9] Sucipto, Irzaman, Tun Tedja Irwadi, Anas Mifta Fauzi. 2011. "Potential of Conductence Measurment for Lard Detection". International Journal of Basic \& Applied Science. IJBAS-IJENS. Vol:11 No:05.

[10] Hassan, K.J, M.S. Zubairu, dan Oyewole R. Olayemi. 2015. Production of Soap From Neem Oil and Acacia nilotica Seed Oil. International Journal of Modern Organic Chemistry. Vol 4, ISSN : 2166-0174, hal 70-84. 
[11] Malik. 2011. Pemanfaatan VCO (Virgin Coconat Oil) Untuk Pembuatan Sabun Padat dengan Penambahan Ekstrak Daun Sirih Merah (Piper Crotum Ruiz \& PAV). Skripsi. Sekolah Tinggi Agama Islam Negeri Batusangkar.

[12] Langingi, Reymon, Lidya I Momuat, maureen G Kumaunang. 2012. Pembuatan Sabun mandi Padat dari VCO yang Mengandung Karotenoid wortel. Jurnal MIPA Vol. 1, No.1, Hal 20-23.

[13] SNI.06-4085.2005. Standarisasi Nasional Indonesia Produk Sabun.

[14] Perdana , Farid Kurnia dan Ibnu Hakim. 2009. Pembuatan Sabun Cair dari Minyak Jarak dan Soda Sebagai Upaya Meningkatkan Pangsa Pasar Soda Q. Skripsi. Semarang : Universitas Diponegoro.

[15] Maripa, Baiq Risni, Yeti Kurniasih, dan Ahmadi. 2010. Pengaruh Konsentrasi Naoh Terhadap Kualitas Sabun Padat Dari Minyak Kelapa (Cocos Nucifera) Yang Ditambahkan Sari Bunga Mawar (Rosa L.). Skripsi. Mataram.

[16] Wijana, Susinggih, Soemarjo, dan Titik Harnawi. 2009. Studi Pembuatan Sabun Mandi Cair Dari Daur Ulang Minyak Goreng Bekas ((Kajian Pengaruh Lama Pengadukan Dan Rasio Air:Sabun Terhadapio Kualitas). Jurnal Teknologi Pertanian Vol. 10 No. 1.

[17] Febrianti, Dwi Rizki. 2013. Formulasi Sediaan Sabun Mandi Cair Minyak Atsiri Jeruk Purut (Citrus Hystrix Dc.) Dengan Kokamidopropil Betain Sebagai Surfaktan. Skripsi. Surakarta : Universitas Muhammadiyah.

[18] Budi, Faleh Seia. 2008. Pemanfaatan Minyak Goreng Bekas dan Soda Q Sebagai Bahan Baku dalam Pembuatan Sabun Cair. Prosiding Semianr Nasional Teknik Kimia “Teknologi Tepat Guna Ramah Lingkungan’ ISBN 978-979-98645-4-9.

[19] Usmania, Diah Irma Ayu and Pertiwi Widya Rahma. "Pembuatan Sabun Transparan dari Minyak Kelapa Murni”. Skripsi. Program Sarjana Fakultas Teknik. Universitas Sebelas Maret. Surakarta. 2012.

[20] Kurnia, Farid and Ibnu Hakim, "Pembuatan Sabun Cair dari Minyak Jarakdan Soda Q Sebagai Upaya Meningkatkan Nilai Paasar Soda Q". J. Tek. Kim. 2010 .

[21] Walter, C. Prester, B. Hoey. “ The Modern Soap Industry”. vol. 2, no. 2, 2000. pp. 1035.

[22] Levenspiel, Octave, 1972, "Chemical Reaction Engineering”, 2nd ed., John Willey and Sons Inc., Singapore.

[23] Muhlisin. 2014. Optimasi Sabun Cair Antibakteri Ekstrak Etanol Rimpang Jahe Merah (Zingiber Officinale Roch.Var. Rubrum) Dengan Variasi Crude Palm Oil (Cpo) Dan Kalium Hidroksida (KOH). Jurnal Mahasiswa Farmasi Fakultas Kedokteran dan Ilmu Kesehatan UNTAN. Vol 1, No 1.

[24] Sari, Tuti Indah, Evy Herdiana, Triana Amelia. "Pembuatan VCO Dengan Metode Enzimatis Dan Konversinya Menjadi Sabun Padat Transparan”. J. Tek. Kimia., 17, no. 3 (2010), pp. 50-58. 